\title{
Biofilms grown in aquatic microcosms affect mercury and selenium accumulation in Daphnia
}

\author{
Semona Issa ${ }^{1} \cdot$ Tomasz Maciej Ciesielski $^{2} \cdot \varnothing y$ vind Mikkelsen $^{3} \cdot$ Sigurd Einum $^{1} \cdot$ Veerle L. B. Jaspers $^{2}$
}

Accepted: 12 March 2020 / Published online: 15 April 2020

(c) The Author(s) 2020

\begin{abstract}
Experiments examining mercury $(\mathrm{Hg})$ toxicity in Daphnia are usually conducted in highly standardized conditions that prevent the formation of biofilm. Although such standardization has many advantages, extrapolation of results to natural conditions and inference of ecological effects is challenging. This is especially true since biofilms can accumulate metals/ metalloids and play a key role in their transfer to higher trophic level organisms. In this study, we experimentally tested the effects of spontaneously appearing biofilm in Daphnia cultures on accumulation of $\mathrm{Hg}$ and its natural antagonist selenium (Se) in Daphnia magna. We added $\mathrm{Hg}$ (in the form of mercury (II) chloride) at two concentrations $(0.2 \mu \mathrm{g} / \mathrm{L}$ and $2 \mu \mathrm{g} / \mathrm{L}$ ) to experimental microcosms and measured the uptake of $\mathrm{Hg}$ and Se by D. magna in the presence and absence of biofilm. To test for consistent and replicable results, we ran two identical experimental sets one week apart. Biofilm presence significantly reduced the accumulation of $\mathrm{Hg}$, while increasing the tissue Se content in D. magna, and these findings were reproducible across experimental sets. These findings indicate that highly standardized tests may not be adequate to predict the bioaccumulation and potential toxicity of metals/metalloids under natural conditions.
\end{abstract}

Keywords Ecotoxicity testing $\cdot$ Trophic transfer $\cdot$ Metal exposure $\cdot$ Biotic interaction

\section{Introduction}

Lab-based aquatic toxicity tests are usually conducted under highly standardized conditions (OECD 1992, 2004), which allows for comparisons of toxicity of different compounds from experiments run in different laboratories and during different times. Yet, extrapolating results of such studies to

Supplementary information The online version of this article (https:// doi.org/10.1007/s10646-020-02194-4) contains supplementary material, which is available to authorized users.

Semona Issa

semona.issa@ntnu.no

Veerle L. B. Jaspers

veerle.jaspers@ntnu.no

1 Department of Biology, Centre for Biodiversity Dynamics (CBD), Norwegian University of Science and Technology,

Høgskoleringen 5, 7491 Trondheim, Norway

2 Department of Biology, Norwegian University of Science and Technology, Høgskoleringen 5, 7491 Trondheim, Norway

3 Department of Chemistry, Norwegian University of Science and Technology, Høgskoleringen 5, 7491 Trondheim, Norway natural populations is challenging, as they overlook the potential for interactions with other components in the biotic community to influence the effects of toxins on focal organisms (Holmstrup et al. 2010; Bone et al. 2012). Daphnia, freshwater zooplankton, are highly suitable for and widely used as model organisms for standardized tests to infer toxicity thresholds of aquatic organisms (Shaw et al. 2008). They are keystone grazers of phytoplankton as well as known consumers of bacteria and fungi (Kagami et al. 2004; Eckert and Pernthaler 2014). Understanding how toxic compounds affect the fitness of Daphnia is essential to understand the ecological consequences of pollution in freshwater ecosystems.

The inclusion of biotic interactions between Daphnia and biofilm in toxicity tests could provide a more ecologically realistic approach. Biofilms are aggregates of microorganisms (algae, cyanobacteria, bacteria, fungi, and protozoa) growing on surfaces and embedded in a matrix of extracellular polymeric substances (EPS; Decho 2000). In aquatic environments, biofilms are involved in organic matter cycling, primary production and respiration (Wetzel 1993; Kühl et al. 1996; Decho 2000). They serve as food to higher trophic levels through grazing (Huws et al. 2005; Siehoff et al. 2009), and their algal components exude organic carbon to be taken up by bacteria (Søndergaard et al. 1995; Goto et al. 2001). 
Despite the role played by biofilms in the aquatic food web, classic toxicity tests apply standardized methods that hinder their growth in exposure media (OECD 2012).

One aspect of biofilms that makes them potentially relevant for toxicity studies is the fact that they efficiently accumulate metals. This makes biofilms useful for monitoring metal contamination in aquatic ecosystems (Leguay et al. 2016), but may also influence the exposure experienced by higher trophic levels (Stewart et al. 2004; Cardoso et al. 2013). For example, aquatic biofilms can readily accumulate mercury (Hg) (Dranguet et al. 2017), as well as its natural antagonist selenium (Se) (Janz et al. 2014). In media and living organisms, selenide ions $\left(\mathrm{Se}^{2-}\right)$ can bind to mercuric ions $\left(\mathrm{Hg}^{2+}\right)$ to form mercuric selenide (HgSe), a stable and biologically inert complex, thereby reducing the risk of $\mathrm{Hg}$ toxic effects. $\mathrm{Se} / \mathrm{Hg}$ molar ratios in organisms that approach or exceed one indicate that toxic effects of $\mathrm{Hg}$ are likely counteracted by Se (Yang et al. 2008). Successful accumulation of $\mathrm{Hg}$ and $\mathrm{Se}$ in biofilms may in turn affect their accumulation in Daphnia.

In this study, we experimentally tested for the effect of biofilm presence on $\mathrm{Hg}$ and Se uptake by Daphnia magna. Biofilm is an important food source for Daphnia (Siehoff et al. 2009) and can provide aquatic animals with an additional source of both $\mathrm{Hg}$ and Se through grazing. Because diet is the main source of Se accumulation in aquatic animals (Sandholm et al. 1973), biofilm is expected to have a positive effect on Se bioaccumulation. On the other hand, direct uptake of $\mathrm{Hg}$ by biofilm could reduce the amount of aqueous $\mathrm{Hg}$ available for uptake by animals (Ayangbenro and Babalola 2017), but may increase their dietary uptake of $\mathrm{Hg}$. Hence, biofilms may play a central role in the transfer of both $\mathrm{Hg}$ and Se to higher trophic levels, possibly altering the effects of $\mathrm{Hg}$ pollution in aquatic ecosystems. Given the high international concern for $\mathrm{Hg}$, due to its long-range transport across the globe and its various toxic properties (UNEP 2013), knowledge about how ecological interactions between Daphnia and biofilms may influence the relative uptake of $\mathrm{Hg}$ and $\mathrm{Se}$ and hence influence toxicity levels, seems crucial, but is currently lacking.

\section{Materials and methods}

\section{Study organisms}

Ephippia containing resting eggs resulting from sexual reproduction of D. magna were collected in November 2014 , in a pond at Værøy Island $\left(1.0 \mathrm{ha}, 67.687^{\circ} \mathrm{N} 12.672^{\circ}\right.$ E), northern Norway. Ephippial eggs were hatched in the laboratory and propagated clonally. For this experiment, juveniles of a single clone (clone 47) of D. magna were asexually propagated for eight successive generations prior to use. D. magna were cultured in $2.5 \mathrm{~L}$ aquaria at $20^{\circ} \mathrm{C}$ in a modified "Aachener Daphnien Medium" (ADaM) (Klüttgen et al. 1994, $\mathrm{SeO}_{2}$ concentration reduced by $50 \%$ ), under long photoperiods (16 h L: $8 \mathrm{~h} \mathrm{D}$ ) using white fluorescent lamps. The medium was exchanged weekly and the animals were fed three times a week with Shellfish Diet $1800^{\circledR}$ (Reed mariculture Inc.; Rikard and Walton 2012) at a final concentration of $3.2 \times 10^{5}$ algal cells $/ \mathrm{mL}$.

\section{Experimental design}

To test for consistent and replicable results, we ran two identical experimental sets (Fig. 1), one week apart, where we allowed for the spontaneous growth of biofilm in the Daphnia culture medium, which may have resulted in differences in biofilm composition between the experimental sets.

For each experimental set, a full factorial design with two different starting concentrations of $\mathrm{Hg}(0.2 \mu \mathrm{g} / \mathrm{L}$ and $2 \mu \mathrm{g} / \mathrm{L})$ and two biofilm treatments (present or absent) was applied, with five replicate beakers for each of the four combinations. In addition, two blanks containing only ADaM medium were used parallel to each experimental set and were treated to the same conditions as the exposure beakers. The two exposure concentrations $(0.2 \mu \mathrm{g} / \mathrm{L}$ and $2 \mu \mathrm{g} / \mathrm{L})$ were selected for being non-lethal and environmentally relevant concentrations of $\mathrm{Hg}$ based on literature research (Table A.1). Hg stock solutions $(0.0016 \mathrm{~g} / \mathrm{L})$ were prepared at the onset of each experimental set, by dissolving $99.5 \%$ pure mercury (II) chloride $\left(\mathrm{HgCl}_{2}\right)$ (Fluka, Switzerland) in Milli-Q water $(18.2 \mathrm{M} \Omega \mathrm{cm})$ (Milli-Q Plus, Millipore Corp.). The exposure glass beakers and equipment used for making $\mathrm{Hg}$ stock solutions were acid-washed overnight before use with $1 \mathrm{M} \mathrm{HNO}_{3}$ suprapure quality prepared with a sub-boiling distillation system (Milestone, SubPUR) and subsequently washed with Milli-Q water. The stock solutions were added to ADaM to create the desired $\mathrm{Hg}$ exposure concentrations. For the biofilm absence treatment, glass beakers were used immediately after the cleaning procedure was completed. For the biofilm presence treatment, glass beakers were allowed to develop biofilm on their walls, in the presence of ten juveniles of a single clone of D. magna
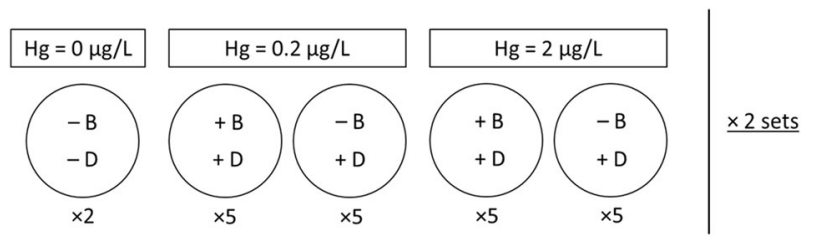

Fig. 1 Schematic diagram of the experimental design. $\times 2$ sets: two identical experimental sets were run one week apart. Two replicates per set for the control $(\times 2), 5$ replicates per treatment $(\times 5)$. Treatments are defined by the $\mathrm{Hg}$ concentration $(0 \mu \mathrm{g} / \mathrm{L} \mathrm{Hg}$ versus $0.2 \mu \mathrm{g} / \mathrm{L} \mathrm{Hg}$ and $2 \mu \mathrm{g} / \mathrm{L} \mathrm{Hg}$ ), presence of biofilm (absent $(-\mathrm{B})$ versus present $(+\mathrm{B})$ ) and presence of Daphnia (absent $(-\mathrm{D})$ versus present $(+\mathrm{D}))$ 
(clone 47), during two weeks prior to the experiment. Moreover, a total of eight controls containing only ADaM were added parallel to the beakers with biofilm and were subjected to identical biofilm growth conditions.

In each experimental replicate beaker $(600 \mathrm{~mL}$ nonaerated borosilicate beakers, Fisherbrand), 30 adults of the same clone were kept in $400 \mathrm{~mL}$ medium at $20{ }^{\circ} \mathrm{C}$ for a period of $96 \mathrm{~h}$. The ADaM medium was not replaced during the experimental period, and the animals were maintained under long photoperiods (16h L: $8 \mathrm{~h} \mathrm{D}$ ) and fed with Shellfish Diet $1800^{\circledR}$ on days 1 and 3 of each experimental set at a final concentration of $3.2 \times 10^{5}$ algal cells $/ \mathrm{mL}$.

\section{Sampling procedure}

On the third day of the biofilm growth period, we sampled the medium in the biofilm-containing beakers and their associated blanks $(n=28)$ for $\mathrm{Hg}$ and $\mathrm{Se}$ analysis. On the first and last experimental days, we sampled $100 \mathrm{~mL}$ of medium for measurements of $\mathrm{pH}$ (WTW $\mathrm{pH} 340 \mathrm{i}$ ), conductivity (WTW LF 330 conductivity meter), and dissolved oxygen (WTW Multi 3410 multiprobe meter), and took $5 \mathrm{~mL}$ of medium for measurements of $\mathrm{Hg}$, Se, chloride $(\mathrm{Cl})$, calcium $(\mathrm{Ca})$ and magnesium $(\mathrm{Mg})(n=88$; experimental beakers and their associated blanks). In addition, ADaM used for $\mathrm{Hg}$ dilution and exposure was sampled $(n=4)$ on the first experimental days for testing of $\mathrm{Hg}$ and Se levels. Immediately after collection, all medium samples $(N=120)$ were filtered through $25 \mathrm{~mm}$ diameter polyethersulphone membrane $(0.45 \mu \mathrm{m})$ disposable syringe filters (VWR International) and acidified to $0.1 \mathrm{M} \mathrm{HNO}_{3}$ (Milestone, SubPUR). Prior to sample withdrawal, the syringe filters were flushed with a few $\mathrm{mL}$ of clean ADaM and subsequently with the medium. $\mathrm{Ca}$ and $\mathrm{Mg}$ concentrations were used to calculate $\mathrm{Ca}$ hardness as follows: $\mathrm{CaCO}_{3}(\mathrm{mg} / \mathrm{L})=$ $2.5 \mathrm{Ca}(\mathrm{mg} / \mathrm{L})+4.1 \mathrm{Mg}(\mathrm{mg} / \mathrm{L})$.

To obtain tissue blanks for $\mathrm{Hg}$ and Se analysis, animals were collected from the Daphnia cultures (clone 47) prior to the start of each experimental set. For analysis of final tissue $\mathrm{Hg}$ and $\mathrm{Se}$ content, animals were sampled on the last experimental day, and then washed in a new culture medium for $5 \mathrm{~min}$ to remove $\mathrm{Hg}$ from the carapace fluid. Finally, all tissue samples $(N=44)$ were freeze-dried and stored at room temperature until further analysis (for more details on quality control check Table A.2).

\section{Chemical analysis}

The medium samples were analyzed using high resolution inductively coupled plasma mass spectrometry (HR-ICPMS, Element 2, Thermo-Fisher Scientific). The freeze-dried tissue samples $(6.30 \pm 0.12 \mathrm{mg}$ dry mass per replicate beaker, mean $\pm \mathrm{SE}$ ) were first acid digested using $3 \mathrm{~mL} 50 \%$
$\mathrm{HNO}_{3}$ per tissue sample (Milestone, SubPUR) in a highpressure microwave system (Milestone UltraClave, EMLS, Leutkirch Germany) according to a temperature profile that increases gradually from room temperature up to $250{ }^{\circ} \mathrm{C}$ within $1 \mathrm{~h}$, followed by a cooling step that allows temperature to return back to its initial value within ca. $1 \mathrm{~h}$. After cooling to room temperature, the digested samples were diluted with Milli-Q water $(18.2 \mathrm{M} \Omega \mathrm{cm}$ ) (Milli-Q Plus, Millipore Corp.) in polypropylene vials to achieve a final $\mathrm{HNO}_{3}$ concentration of $0.6 \mathrm{M}$. Finally, samples were analyzed with HR-ICP-MS and the tissue Hg and Se content was calculated on a dry-mass basis. Seven blank samples containing Milli-Q water and $\mathrm{HNO}_{3}(0.6 \mathrm{M}$ in final solution) were run parallel to the digestion of the tissue samples. Results were corrected for reagent blank values. Certified reference material Polish Virginia Tobacco Leaves (INCT-PVTL-6) (Samczyński et al. 2012) was used to verify the accuracy of the $\mathrm{Hg}$ and $\mathrm{Se}$ analysis. The mean concentrations found $(0.0264 \pm 0.0006 \mu \mathrm{g} / \mathrm{g}$ dry weight $)$ were in good agreement with the certified values $(0.0232 \pm 0.0016 \mu \mathrm{g} / \mathrm{g}$ dry weight $)$.

\section{Statistical analysis}

All statistical analyses and graphic illustrations were performed in R v. 3.4.3. (R Development Core Team 2016). For exposure and water quality variables $(\mathrm{Hg}, \mathrm{Se}, \mathrm{Cl}$, calcium hardness, dissolved oxygen, conductivity and $\mathrm{pH}$ ), summary statistics (mean \pm standard error) were calculated and full models were fitted using $\mathrm{Hg}$ concentration, biofilm and experimental set (hereafter "set") as fixed predictor variables and replicate beaker as a random predictor variable. For tissue $\mathrm{Hg}$ and $\mathrm{Se}$ content and $\mathrm{Se} / \mathrm{Hg}$ molar ratios in Daphnia, full models with fixed predictor variables being $\mathrm{Hg}$ concentration, biofilm and set were fitted.

The models were implemented using the lme and gls functions in the package nlme (Pinheiro et al. 2018). Model selection followed a backwards selection procedure, where variables were removed sequentially, starting with random effects, using likelihood ratio tests (Zuur et al. 2009). Model residuals were checked for homogeneous variance and for normal distribution. The VarIdent command from the nlme package was used to allow residual variance to differ among Hg concentrations, biofilm levels and sets. Tukey's multiple comparison test was implemented where groups were significantly different. We used a significance level $\alpha=0.05$ for hypothesis testing.

\section{Results}

No mortality occurred during the exposure. The $\mathrm{Hg}$ concentration was significantly higher in media without biofilm compared to media with biofilm that were exposed to $2 \mu \mathrm{g} / \mathrm{L}$ 
$\mathrm{Hg}$ in set 1 only (Table 1 ). Se in the medium, $\mathrm{pH}$ and conductivity significantly decreased in the presence of biofilm (Table 1). Furthermore, $\mathrm{Cl}$, hardness and conductivity were significantly higher in set 1 compared to set 2 (Table 1). The opposite was true for $\mathrm{pH}$ and dissolved oxygen (Table 1). In addition, dissolved oxygen significantly increased in the presence of biofilm in set 1 only (Table 1). Nevertheless, despite significant effects of treatments and/or sets on conductivity, dissolved oxygen, $\mathrm{pH}, \mathrm{Cl}$ and hardness, the magnitude of change in these measures was relatively small. Indeed, $\mathrm{pH}$, conductivity and $\mathrm{Cl}$ varied by a maximum of $5 \%$, hardness by $8 \%$ and dissolved oxygen by $11 \%$ (Table 1 ).

Tissue $\mathrm{Hg}$ content was significantly higher in daphnids exposed to $2 \mu \mathrm{g} / \mathrm{L} \mathrm{Hg}$ compared to $0.2 \mu \mathrm{g} / \mathrm{L} \mathrm{Hg}(6.1 \pm$ $0.5 \mu \mathrm{g} / \mathrm{g}$ dry mass versus $0.8 \pm 0.07 \mu \mathrm{g} / \mathrm{g}$ dry mass, $P<$ $0.001)$ and approximately twofold higher in set 2 compared to set $1(4.6 \pm 0.8 \mu \mathrm{g} / \mathrm{g}$ dry mass versus $2.4 \pm 0.4 \mu \mathrm{g} /$ g dry mass, $P<0.001$ ) (Fig. 2 ). In addition, biofilm presence significantly reduced the overall Daphnia tissue $\mathrm{Hg}$ content from $0.9 \pm 0.1$ to $0.7 \pm 0.1 \mu \mathrm{g} / \mathrm{g}$ dry mass at $0.2 \mu \mathrm{g} /$ $\mathrm{L} \mathrm{Hg}$, and from $6.4 \pm 0.7$ to $5.8 \pm 0.7 \mu \mathrm{g} / \mathrm{g}$ dry mass at $2 \mu \mathrm{g} / \mathrm{L} \mathrm{Hg}(P<0.001)$ (Fig. 2). On the other hand, the overall Daphnia tissue Se content significantly increased in the presence of biofilm from $3.4 \pm 0.2 \mu \mathrm{g} / \mathrm{g}$ dry mass to $5.1 \pm 0.1 \mu \mathrm{g} / \mathrm{g}$ dry mass $(P<0.001)$ (Fig. 3). Consequently, $\mathrm{Se} / \mathrm{Hg}$ molar ratios significantly increased in the presence of biofilm in set 1 from $11 \pm 0.9$ (no biofilm) to $31 \pm 2.1$ (with biofilm; $P<0.001$ ) under exposure to $0.2 \mu \mathrm{g} / \mathrm{L} \mathrm{Hg}$ and from $1.8 \pm 0.1$ (no biofilm) to $3.5 \pm 0.1$ (with biofilm; $P<0.001$ ) under exposure to $2 \mu \mathrm{g} / \mathrm{L} \mathrm{Hg}$. However, biofilm presence did not significantly affect molar ratios in set $2(12 \pm 0.7$ versus $8.8 \pm 1.1$ at $0.2 \mu \mathrm{g} / \mathrm{L}$ $\mathrm{Hg}$, ns, and $1.6 \pm 0.1$ versus $1.1 \pm 0.1$ at $2 \mu \mathrm{g} / \mathrm{L} \mathrm{Hg}$, ns)
(Fig. 4). More detailed results can be found in the Supplementary Material Tables A.3 and A.4.

\section{Discussion}

In this study, we examined whether biofilm could affect $\mathrm{Hg}$ and Se accumulation in Daphnia magna through aqueous and dietary uptake pathways. The $\mathrm{Hg}$ exposure concentrations used were lower than the acute $\mathrm{LC}_{50}$ of $2.2 \mu \mathrm{g} / \mathrm{L} \mathrm{Hg}$ in cladocerans (Nichols et al. 1997), although exceeding mean total concentrations of $0.006 \mu \mathrm{g} / \mathrm{L}$ typically found in the aquatic environment (Chen et al. 2000). Conductivity, dissolved oxygen and $\mathrm{pH}$ were also within the recommended range for testing metals in OECD test protocols for this species (OECD 2004). While hardness exceeded the recommended range, hardness has a negligible effect on $\mathrm{Hg}$ toxicity, in contrast to other heavy metals (Rathore and Khangarot 2003). Overall, there was no observed Daphnia mortality from either $\mathrm{Hg}$ exposure or changes in water quality.

There was a clear difference in $\mathrm{Hg}$ bioaccumulation between experimental sets, with higher tissue $\mathrm{Hg}$ content in set 2 compared to set 1 . This was not due to differences in medium $\mathrm{Hg}$ concentrations but was possibly related to the higher medium $\mathrm{Cl}$ concentrations in set 1 . Increased $\mathrm{Cl}$ has been shown to reduce the bioavailability of inorganic $\mathrm{Hg}$ through speciation (Wang and Wang 2010). In addition, dissolved organic carbon (DOC) could differ between sets, although this was not assessed in the current study. It is therefore important to always record and consider the potential influence of water quality variables when interpreting results from experimental exposure studies in aquatic microcosms. Moreover, differences between sets

Table 1 Exposure and water quality variable averages (averaged over the first and last experimental days) are compared across all sets and treatment combinations

\begin{tabular}{|c|c|c|c|c|c|c|c|c|}
\hline \multirow[b]{3}{*}{ Set } & \multicolumn{8}{|l|}{ Treatment } \\
\hline & \multicolumn{2}{|c|}{ Biofilm present $0.2 \mathrm{Hg}(\mu \mathrm{g} / \mathrm{L})$} & \multicolumn{2}{|c|}{ Biofilm absent $0.2 \mathrm{Hg}(\mu \mathrm{g} / \mathrm{L})$} & \multicolumn{2}{|c|}{ Biofilm present $2 \mathrm{Hg}(\mu \mathrm{g} / \mathrm{L})$} & \multicolumn{2}{|c|}{ Biofilm absent $2 \mathrm{Hg}(\mu \mathrm{g} / \mathrm{L})$} \\
\hline & 1 & 2 & 1 & 2 & 1 & 2 & 1 & 2 \\
\hline $\mathrm{Hg}^{2+}(\mu \mathrm{g} / \mathrm{L})$ & $0.024 \pm 0.003^{\mathrm{a}}$ & $0.026 \pm 0.003^{\mathrm{a}}$ & $0.050 \pm 0.01^{\mathrm{a}}$ & $0.027 \pm 0.01^{\mathrm{a}}$ & $0.12 \pm 0.01^{\mathrm{a}}$ & $0.15 \pm 0.02^{\mathrm{a}}$ & $0.51 \pm 0.1^{\mathrm{b}}$ & $0.14 \pm 0.03^{\mathrm{a}}$ \\
\hline $\mathrm{Se}^{2-}(\mu \mathrm{g} / \mathrm{L})$ & $5.8 \pm 0.05^{\mathrm{b}}$ & $5.7 \pm 0.1^{b}$ & $5.9 \pm 0.05^{\mathrm{a}}$ & $5.9 \pm 0.09^{\mathrm{a}}$ & $5.7 \pm 0.06^{\mathrm{b}}$ & $5.7 \pm 0.07^{b}$ & $5.9 \pm 0.04^{\mathrm{a}}$ & $5.7 \pm 0.04^{\mathrm{a}}$ \\
\hline $\begin{array}{l}\text { Conductivity } \\
(\mathrm{mS} / \mathrm{cm})\end{array}$ & $2.2 \pm 0.004^{\mathrm{bc}}$ & $2.1 \pm 0.01^{\mathrm{bd}}$ & $2.2 \pm 0.01^{\mathrm{ac}}$ & $2.2 \pm 0.01^{\mathrm{ad}}$ & $2.2 \pm 0.004^{b c}$ & $2.1 \pm 0.01^{\mathrm{bd}}$ & $2.3 \pm 0.002^{\mathrm{ac}}$ & $2.1 \pm 0.01^{\mathrm{ad}}$ \\
\hline $\begin{array}{l}\text { Dissolved } \\
\text { oxygen }(\mathrm{mg} / \mathrm{L})\end{array}$ & $7.9 \pm 0.05^{b c}$ & $8.1 \pm 0.1^{\mathrm{bd}}$ & $7.5 \pm 0.08^{\mathrm{a}}$ & $8.2 \pm 0.06^{\mathrm{bd}}$ & $7.8 \pm 0.1^{\mathrm{bc}}$ & $8.2 \pm 0.1^{\mathrm{bd}}$ & $7.6 \pm 0.02^{\mathrm{a}}$ & $8.3 \pm 0.1^{\mathrm{bd}}$ \\
\hline $\mathrm{pH}$ & $7.7 \pm 0.02^{\mathrm{bc}}$ & $7.8 \pm 0.04^{\mathrm{bd}}$ & $7.8 \pm 0.04^{\mathrm{ac}}$ & $7.9 \pm 0.02^{\mathrm{ad}}$ & $7.7 \pm 0.02^{\mathrm{bc}}$ & $7.9 \pm 0.05^{\mathrm{bd}}$ & $7.8 \pm 0.05^{\mathrm{ac}}$ & $8.0 \pm 0.08^{\mathrm{ad}}$ \\
\hline $\mathrm{Ca}$ hardness $(\mathrm{mg} / \mathrm{L})$ & $350 \pm 3^{\mathrm{a}}$ & $320 \pm 10^{\mathrm{b}}$ & $340 \pm 5^{\mathrm{a}}$ & $340 \pm 4^{\mathrm{b}}$ & $340 \pm 5^{\mathrm{a}}$ & $320 \pm 8^{\mathrm{b}}$ & $340 \pm 3^{\mathrm{a}}$ & $330 \pm 8^{b}$ \\
\hline $\mathrm{Cl}^{-}(\mathrm{mg} / \mathrm{L})$ & $630 \pm 4^{\mathrm{a}}$ & $605 \pm 9^{b}$ & $630 \pm 6^{\mathrm{a}}$ & $610 \pm 8^{b}$ & $630 \pm 3^{\mathrm{a}}$ & $602 \pm 6^{\mathrm{b}}$ & $630 \pm 3^{\mathrm{a}}$ & $610 \pm 6^{\mathrm{b}}$ \\
\hline
\end{tabular}

Values are given as mean \pm SE. Means with the same letter are not significantly different from each other 


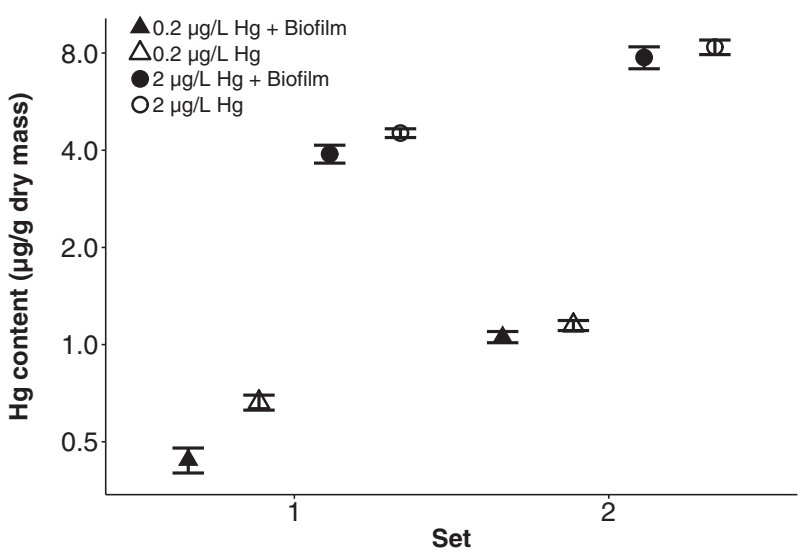

Fig. 2 Tissue Hg content ( $\mu \mathrm{g} / \mathrm{g}$ dry mass) in Daphnia in response to growth medium $\mathrm{Hg}$ concentrations, biofilm presence versus absence and set $($ mean $\pm S E)$. The $y$-axis is on a logarithmic scale with base 2

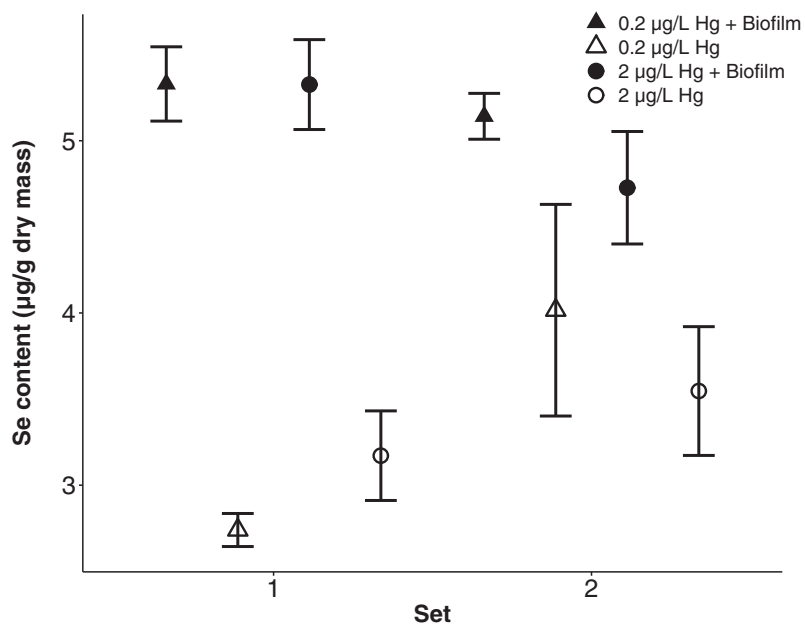

Fig. 3 Tissue Se content ( $\mu \mathrm{g} / \mathrm{g}$ dry mass) in Daphnia in response to growth medium $\mathrm{Hg}$ concentrations, biofilm presence versus absence and set (mean $\pm \mathrm{SE})$. The y-axis is on a linear scale

could be due to a potential difference in Daphnia age, albeit unlikely, and evidence to support this is currently lacking.

Daphnia tissue analysis showed that the increase in $\mathrm{Hg}$ content with increasing medium $\mathrm{Hg}$ concentrations was less significant in the presence of biofilm. Furthermore, biofilm presence increased Daphnia tissue Se content. These findings were replicable across experimental sets, which is important to highlight, as consistent and replicable effects are critical for improving risk analysis approaches (National Research Council 2009).

Previous research has provided evidence of aquatic biofilms accumulating heavy metals (Hill and Larsen 2005; Kohušová et al. 2011), through rapid absorption and removal from the aqueous solution (Chang et al. 2006; Ancion et al. 2010). This is because biofilms have a high capacity to absorb metals, which makes them a useful bioremediation tool (Dixit et al. 2015). Therefore,

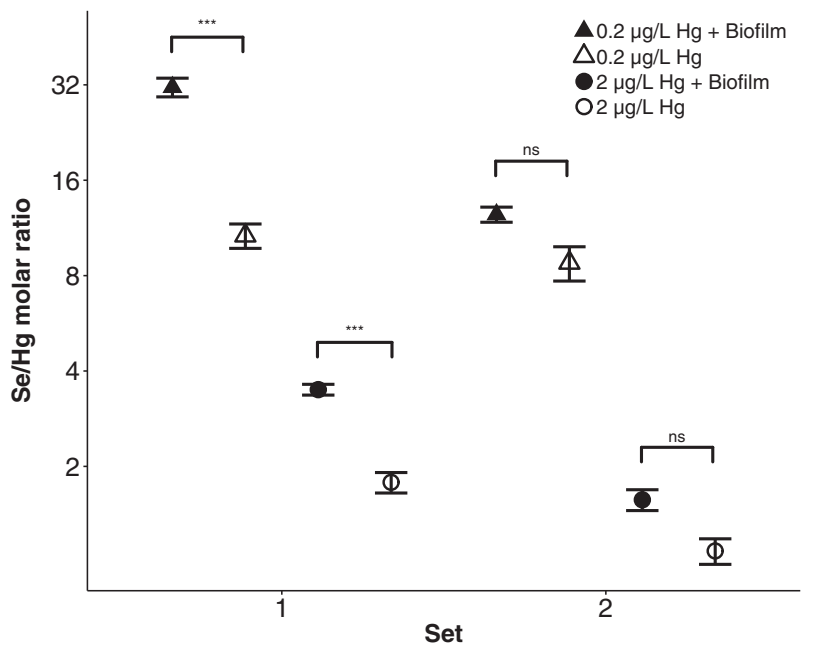

Fig. $4 \mathrm{Se} / \mathrm{Hg}$ molar ratios in Daphnia in response to growth medium $\mathrm{Hg}$ concentrations, biofilm presence versus absence and set (mean \pm SE). Significance was evaluated using the Tukey's HSD post hoc test. Significant differences were observed between the two biofilm treatments for set 1 only (***P<0.001; ns not significant). The y-axis is on a logarithmic scale with base 2

the biofilm in our study may potentially have acted as an available dietary source of $\mathrm{Hg}$ to the Daphnia, which could however not be confirmed as we were unable to analyze the $\mathrm{Hg}$ and $\mathrm{Se}$ content in the whole biofilm in this study. To determine the total mass balance of $\mathrm{Hg}$ and $\mathrm{Se}$ (total mass of biofilm and its $\mathrm{Hg}$ and Se content) in the exposure beakers, we would need to sample the entirety of the biofilm from the beakers. This was unfortunately not possible as it adhered to the walls and could not be entirely scraped off. Future studies should consider the possibility of growing the biofilm in filters placed inside the beakers at the start of the experiment for collection later. However, Tsui and Wang (2004) showed that $D$. magna accumulated $\mathrm{Hg}$ (II) mainly from the aqueous phase, through absorption, rather than from the ingestion of $\mathrm{Hg}$ enriched food. In the current study, uptake of aqueous $\mathrm{Hg}$ by daphnids may have been more important than dietary uptake as the presence of biofilm decreased the accumulation of $\mathrm{Hg}$ in the Daphnia. Indeed, biofilm may have indirectly reduced $\mathrm{Hg}$ accumulation in the animals, by reducing the amount of bioavailable aqueous $\mathrm{Hg}$. However, this is not supported by our measurements in the medium, as observed changes in medium $\mathrm{Hg}$ concentrations (Table 1) do not suggest extensive uptake of the metal by biofilm.

Alternatively, biofilms can further reduce metal accumulation at higher trophic levels through "bloom dilution", whereby increased phytoplankton biomass reduces the concentration of metal per cell available to grazers (Pickhardt et al. 2002). Another phenomenon is "growth biodilution", observed in rapidly growing phytoplankton, 
where the concentration of metals within cells is diluted by growth during the day (measured as photosynthetically fixed carbon) (Hill and Larsen 2005; Poste et al. 2015). Hill and Larsen (2005) showed how this phenomenon substantially decreased metal concentrations in biofilm within a short period of 4 days, equal to the duration of the current experiment. Thus, if biofilm was an important dietary source of Hg to the Daphnia in the current study, the animals would have been exposed to lower $\mathrm{Hg}$ concentrations from diet than from the aqueous phase because of "growth biodilution". However, it was not possible to determine unambiguously the main source of $\mathrm{Hg}$ to the daphnids in our study, as we were unable to determine the total mass balance of $\mathrm{Hg}$ (total mass of biofilm and its $\mathrm{Hg}$ content) in the exposure beakers.

Although the exact mode of action of biofilm presence on $\mathrm{Hg}$ accumulation in Daphnia is unknown, the presence of biofilm significantly reduced tissue $\mathrm{Hg}$ content and increased tissue Se content in Daphnia. The latter suggests dietary uptake of Se from biofilm. Lower Se concentrations measured in media with biofilm imply the metalloid's uptake by biofilm microorganisms. Indeed, biofilm components are known to readily absorb Se under both laboratory and field conditions, rendering it bioavailable to higher trophic levels through diet (Fan et al. 2002; Ranjard et al. 2003; Tuzen and Sar1 2010). In agreement with the majority of studies that have investigated Se transfer in aquatic ecosystems (Stewart et al. 2004; Conley et al. 2009), our findings support that diet may be the predominant route of Se exposure for organisms in aquatic food webs. Nevertheless, at high aqueous Se concentrations, the proportion of dietary to direct Se uptake may decrease. This was previously detected in daphnids exposed to $31.6 \mu \mathrm{g} / \mathrm{L}$ Se (Guan and Wang 2004), a concentration that is however far above those observed in the current experiment.

Biofilm-induced changes in tissue $\mathrm{Se}$ and $\mathrm{Hg}$ content led to an increase in $\mathrm{Se} / \mathrm{Hg}$ molar ratios in the animals, which remained above one in all treatments. This suggests that tissue Se content was probably high enough to counteract toxic effects of $\mathrm{Hg}$ in the Daphnia in the current experiment (Peterson et al. 2009).

In summary, the presence of biofilm reduced $\mathrm{Hg}$ accumulation in Daphnia. This reduction was probably not due to a reduction in dissolved $\mathrm{Hg}$ available to animals or to "growth biodilution" in the biofilm, as these processes would require significant uptake of $\mathrm{Hg}$ by the biofilm, which was not supported by observed changes in medium $\mathrm{Hg}$ concentrations. Therefore, the exact driver of the lower tissue $\mathrm{Hg}$ content in the presence of biofilm remains unknown and future analysis of biofilm content and DOC is strongly recommended. On the other hand, the presence of biofilm increased the accumulation of $\mathrm{Se}$ in the animals. Thus, biofilms could play a central role in the transfer of Se through the freshwater food web, subsequently providing potential protection against $\mathrm{Hg}$ toxicity in the animals. Thus, aquatic biofilms can affect the transfer of $\mathrm{Hg}$ and $\mathrm{Se}$ to grazing zooplankton, which then act as conduits of $\mathrm{Hg}$ and Se to subsequent higher trophic levels of the food web. Our findings support the observation that including natural variability in toxicity studies and allowing for food web interactions may be important for more realistic environmental exposure assessments (De Laender et al. 2008; Viaene et al. 2015). Therefore, in order to obtain ecologically relevant results, we recommend that aquatic toxicity studies on metals/metalloids should include interactions with biofilm components. However, further research is necessary to conclude on the main mechanism of $\mathrm{Hg}$ and $\mathrm{Se}$ accumulation in Daphnia in the presence of biofilm.

Acknowledgements Financial support was provided by the Norwegian University of Science and Technology (NTNU) and the Research Council of Norway, project 223257/F50. We thank Ane Simonsen, Hanna-Kaisa Lakka, Grethe Stavik Eggen, Syverin Lierhagen and the staff at our lab facility for technical assistance. Open Access funding provided by NTNU Norwegian University of Science and Technology (incl St. Olavs Hospital - Trondheim University Hospital).

\section{Compliance with ethical standards}

Conflict of interest The authors declare that they have no conflict of interest.

Ethical approval All applicable international, national, and/or institutional guidelines for the care and use of animals were followed. This study does not contain any studies with human participants performed by any of the authors.

Informed Consent This study does not contain any studies with human participants performed by any of the authors.

Publisher's note Springer Nature remains neutral with regard to jurisdictional claims in published maps and institutional affiliations.

Open Access This article is licensed under a Creative Commons Attribution 4.0 International License, which permits use, sharing, adaptation, distribution and reproduction in any medium or format, as long as you give appropriate credit to the original author(s) and the source, provide a link to the Creative Commons license, and indicate if changes were made. The images or other third party material in this article are included in the article's Creative Commons license, unless indicated otherwise in a credit line to the material. If material is not included in the article's Creative Commons license and your intended use is not permitted by statutory regulation or exceeds the permitted use, you will need to obtain permission directly from the copyright holder. To view a copy of this license, visit http://creativecommons. org/licenses/by/4.0/.

\section{References}

Ancion P-Y, Lear G, Lewis GD (2010) Three common metal contaminants of urban runoff $(\mathrm{Zn}, \mathrm{Cu} \& \mathrm{~Pb})$ accumulate in 
freshwater biofilm and modify embedded bacterial communities. Environ Pollut 158(8):2738-2745. https://doi.org/10.1016/j. envpol.2010.04.013

Ayangbenro AS, Babalola OO (2017) A new strategy for heavy metal polluted environments: a review of microbial biosorbents. Int $\mathbf{J}$ Environ Res Public Health 14(1):94. https://doi.org/10.3390/ ijerph14010094

National Research Council (2009) Science and decisions: advancing risk assessment. The National Academies Press, Washington, DC

Bone AJ, Colman BP, Gondikas AP, Newton KM, Harrold KH, Cory RM, Unrine JM, Klaine SJ, Matson CW, Di Giulio RT (2012) Biotic and abiotic interactions in aquatic microcosms determine fate and toxicity of $\mathrm{Ag}$ nanoparticles: part 2-toxicity and $\mathrm{Ag}$ speciation. Environ Sci Technol 46(13):6925-6933. https://doi. org/10.1021/es204683m

Cardoso PG, Marques SC, D'Ambrosio M, Pereira E, Duarte AC, Azeiteiro UM, Pardal MÂ (2013) Changes in zooplankton communities along a mercury contamination gradient in a coastal lagoon (Ria de Aveiro, Portugal). Mar Pollut Bull 76(1):170-177. https://doi.org/10.1016/j.marpolbul.2013.09.007

Chang WC, Hsu GS, Chiang SM, Su MC (2006) Heavy metal removal from aqueous solution by wasted biomass from a combined ASbiofilm process. Bioresour Technol 97(13):1503-1508. https:// doi.org/10.1016/j.biortech.2005.06.011

Chen CY, Stemberger RS, Klaue B, Blum JD, Pickhardt PC, Folt CL (2000) Accumulation of heavy metals in food web components across a gradient of lakes. Limnol Oceanogr 45(7):1525-1536. https://doi.org/10.4319/lo.2000.45.7.1525

OECD (2012) Test No. 211: daphnia magna reproduction test OECD guidelines for the testing of chemicals, section 2. OECD Publishing, Paris

Conley JM, Funk DH, Buchwalter DB (2009) Selenium bioaccumulation and maternal transfer in the mayfly Centroptilum triangulifer in a life-cycle, periphyton-biofilm trophic assay. Environ Sci Technol 43(20):7952-7957. https://doi.org/10.1021/es9016377

Decho AW (2000) Microbial biofilms in intertidal systems: an overview. Cont Shelf Res 20(10):1257-1273. https://doi.org/10.1016/ S0278-4343(00)00022-4

Dixit R, Wasiullah, Malaviya D, Pandiyan K, Singh U, Sahu A, Shukla R, Singh B, Rai J, Sharma P, Lade H, Paul D (2015) Bioremediation of heavy metals from soil and aquatic environment: an overview of principles and criteria of fundamental processes. Sustainability 7(2):2189-2212. https://doi.org/10. $3390 /$ su7022189

OECD (1992) Test No. 203: fish, acute toxicity test OECD guidelines for the testing of chemicals, section 2. OECD Publishing, Paris

R Development Core Team (2016) R: a language and environment for statistical computing. R Foundation for Statistical Computing, Vienna, Austria

Dranguet P, Faucheur SL, Slaveykova VI (2017) Mercury bioavailability, transformations, and effects on freshwater biofilms. Environ Toxicol Chem 9999:1-12. https://doi.org/10.1002/etc. 3934

Eckert EM, Pernthaler J (2014) Bacterial epibionts of Daphnia: a potential route for the transfer of dissolved organic carbon in freshwater food webs. ISME 8(9):1808-1819. https://doi.org/10. 1038/ismej.2014.39

UNEP (2013) Global mercury assessment 2013: sources, emissions, releases and environmental transport. UNEP Chemicals Branch, Geneva, Switzerland

Fan TWM, Teh SJ, Hinton DE, Higashi RM (2002) Selenium biotransformations into proteinaceous forms by foodweb organisms of selenium-laden drainage waters in California. Aquat Toxicol 57(1):65-84. https://doi.org/10.1016/S0166-445X(01)00261-2

Goto N, Mitamura O, Terai H (2001) Biodegradation of photosynthetically produced extracellular organic carbon from intertidal benthic algae. J Exp Mar Biol Ecol 257(1):73-86. https://doi.org/10.1016/S0022-0981(00)00329-4

Guan R, Wang W-X (2004) Dietary assimilation and elimination of $\mathrm{Cd}$, Se, and $\mathrm{Zn}$ by Daphnia magna at different metal concentrations. Environ Toxicol Chem 23(11):2689-2698. https:// doi.org/10.1897/03-503

Hill WR, Larsen IL (2005) Growth dilution of metals in microalgal biofilms. Environ Sci Technol 39(6):1513-1518. https://doi.org/ 10.1021/es049587y

Holmstrup M, Bindesbøl A-M, Oostingh GJ, Duschl A, Scheil V, Köhler H-R, Loureiro S, Soares AMVM, Ferreira ALG, Kienle C, Gerhardt A, Laskowski R, Kramarz PE, Bayley M, Svendsen C, Spurgeon DJ (2010) Interactions between effects of environmental chemicals and natural stressors: a review. Sci Total Environ 408(18):3746-3762. https://doi.org/10.1016/j.scitotenv. 2009.10.067

Huws SA, McBain AJ, Gilbert P (2005) Protozoan grazing and its impact upon population dynamics in biofilm communities. J Appl Microbiol 98(1):238-244. https://doi.org/10.1111/j.1365-2672. 2004.02449.x

Janz DM, Liber K, Pickering IJ, Wiramanaden CIE, Weech SA, Gallego-Gallegos M, Driessnack MK, Franz ED, Goertzen MM, Phibbs J, Tse JJ, Himbeault KT, Robertson EL, Burnett-Seidel C, England K, Gent A (2014) Integrative assessment of selenium speciation, biogeochemistry, and distribution in a northern coldwater ecosystem. Integr Environ Assess Manag 10(4):543-554. https://doi.org/10.1002/ieam.1560

OECD (2004) Test No. 202: daphnia sp. acute immobilisation test OECD guidelines for the testing of chemicals, section 2. OECD Publishing, Paris

Kagami M, Donk EV, De Bruin A, Rijkeboer M, Ibelings BW (2004) Daphnia can protect diatoms from fungal parasitism. Limnol Oceanogr 49(3):680-685

Klüttgen B, Dülmer U, Engels M, Ratte HT (1994) ADaM, an artificial freshwater for the culture of zooplankton. Water Res 28:743-746

Kohušová K, Havel L, Vlasák P, Tonika J (2011) A long-term survey of heavy metals and specific organic compounds in biofilms, sediments, and surface water in a heavily affected river in the Czech Republic. Environ Monit Assess 174:555-572. https://doi. org/10.1007/s10661-010-1478-4

Kühl M, Glud RN, Ploug H, Ramsing NB (1996) Microenvironmental control of photosynthesis and photosynthesis-coupled respiration in an epilithic cyanobacterial biofilm. J Phycol 32(5):799-812. https://doi.org/10.1111/j.0022-3646.1996.00799.x

De Laender F, De Schamphelaere KAC, Vanrolleghem PA, Janssen CR (2008) Do we have to incorporate ecological interactions in the sensitivity assessment of ecosystems? An examination of a theoretical assumption underlying species sensitivity distribution models. Environ Int 34(3):390-396. https://doi.org/10.1016/j. envint.2007.09.006

Leguay S, Lavoie I, Levy JL, Fortin C (2016) Using biofilms for monitoring metal contamination in lotic ecosystems: the protective effects of hardness and $\mathrm{pH}$ on metal bioaccumulation. Environ Toxicol Chem 35(6):1489-1501. https://doi.org/10. 1002/etc. 3292

Nichols JW, Ambrose RB Jr, Cubbison C, Fairbrother A, Keating MH, Mahaffey KR, Mukerjee D, Rice GE, Reisman DJ, Schoeny R, Swartout J, Troyer M (1997) Mercury study report to congress. Volume VI: an ecological assessment for anthropogenic mercury emissions in the United States EPA-452/R-97-008. U.S. EPA Office of Air Quality Planning and Standards and Office of Research and Development, Washington, DC

Peterson SA, Ralston NVC, Whanger PD, Oldfield JE, Mosher WD (2009) Selenium and mercury interactions with emphasis on fish tissue. Environ Bioindic 4:318-334. https://doi.org/10.1080/ 15555270903358428 
Pickhardt PC, Folt CL, Chen CY, Klaue B, Blum JD (2002) Algal blooms reduce the uptake of toxic methylmercury in freshwater food webs. Proc Natl Acad Sci 99(7):4419-4423. https://doi.org/ 10.1073/pnas.072531099

Pinheiro J, Bates D, DebRoy S, Sarkar D, R Core Team (2018) nlme: linear and nonlinear mixed effects models (Version $\mathrm{R}$ package version 3.1-131.1). https://CRAN.R-project.org/package $=$ nlme

Poste AE, Muir DCG, Guildford SJ, Hecky RE (2015) Bioaccumulation and biomagnification of mercury in African lakes: the importance of trophic status. Sci Total Environ 506-507:126-136. https://doi.org/10.1016/j.scitotenv.2014.10.094

Ranjard L, Nazaret S, Cournoyer B (2003) Freshwater bacteria can methylate selenium through the thiopurine methyltransferase pathway. Appl Environ Microbiol 69(7):3784-3790. https://doi. org/10.1128/AEM.69.7.3784-3790.2003

Rathore RS, Khangarot BS (2003) Effects of water hardness and metal concentration on a freshwater Tubifex Tubifex Muller. Water, Air, Soil Pollut 142(1):341-356. https://doi.org/10. 1023/a:1022016021081

Rikard FS, Walton WC (2012) Use of microalgae concentrates for rearing oyster larvae, Crassostrea virginica. Mississippi-Alabama Sea Grant Publication No.: MASGP-12-048

Samczyński Z, Dybczyński RS, Polkowska-Motrenko H, Chajduk E, Pyszynska M, Danko B, Czerska E, Kulisa K, Doner K, Kalbarczyk P (2012) Two new reference materials based on tobacco leaves: certification for over a dozen of toxic and essential elements. Sci World J. https://doi.org/10.1100/2012/216380

Sandholm M, Oksanen HE, Pesonen L (1973) Uptake of selenium by aquatic organisms. Limnol Oceanogr 18(3):496-499. https://doi. org/10.4319/lo.1973.18.3.0496

Shaw JR, Pfrender ME, Eads BD, Klaper R, Callaghan A, Sibly RM, Colson I, Jansen B, Gilbert D, Colbourne JK (2008) Daphnia as an emerging model for toxicological genomics. Adv Exp Biol 2:165-219. https://doi.org/10.1016/S1872-2423(08)00005-7

Siehoff S, Hammers-wirtz M, Strauss T, Toni H (2009) Periphyton as alternative food source for the filter-feeding cladoceran Daphnia magna. Freshw Biol 54:15-23. https://doi.org/10.1111/j.13652427.2008.02087.x

Søndergaard M, Hansen B, Markager S (1995) Dynamics of dissolved organic carbon lability in a eutrophic lake. Limnol Oceanogr 40 (1):46-54. https://doi.org/10.4319/lo.1995.40.1.0046

Stewart AR, Luoma SN, Schlekat CE, Doblin MA, Hieb KA (2004) Food web pathway determines how selenium affects aquatic ecosystems: a San Francisco Bay case study. Environ Sci Technol 38(17):4519-4526. https://doi.org/10.1021/es0499647

Tsui MTK, Wang W-X (2004) Uptake and elimination routes of inorganic mercury and methylmercury in Daphnia magna. Environ Sci Technol 38(3):808-816. https://doi.org/10.1021/es034638x

Tuzen M, Sarı A (2010) Biosorption of selenium from aqueous solution by green algae (Cladophora hutchinsiae) biomass: Equilibrium, thermodynamic and kinetic studies. Chem Eng J 158(2):200-206. https://doi.org/10.1016/j.cej.2009.12.041

Viaene KPJ, De Laender F, Rico A, Van den Brink PJ, Di Guardo A, Morselli M, Janssen CR (2015) Species interactions and chemical stress: combined effects of intraspecific and interspecific interactions and pyrene on Daphnia magna population dynamics. Environ Toxicol Chem 34(8):1751-1759. https://doi.org/10. 1002/etc. 2973

Wang R, Wang W-X (2010) Importance of speciation in understanding mercury bioaccumulation in tilapia controlled by salinity and dissolved organic matter. Environ Sci Technol 44 (20):7964-7969. https://doi.org/10.1021/es1011274

Wetzel RG (1993) Microcommunities and microgradients: linking nutrient regeneration, microbial mutualism, and high sustained aquatic primary production. Neth J Aquat Ecol 27(1):3-9. https:// doi.org/10.1007/bf02336924

Yang D-Y, Chen Y-W, Gunn JM, Belzile N (2008) Selenium and mercury in organisms: interactions and mechanisms. Environ Rev 16:71-92. https://doi.org/10.1139/A08-001

Zuur AF, Ieno EN, Walker NJ, Saveliev AA, Smith GM (2009) Mixed effects models and extensions in ecology with R. Springer, New York, NY 